\title{
Upaya Kepala Sekolah dalam Pemberdayaan Pegawai Tata Usaha di SMA Negeri 1 Pseksu Kabupaten Lahat \\ Andrianto \\ UIN Sunan Kalijaga Yogyakarta
}

\begin{abstract}
This study takes the title "Efforts of School Principals in Empowering Administrative Employees in SMA Negeri 1 PSEKSU Kab. Lahat ". The problem in this thesis is how the principal's efforts in empowering administrative staff in SMA Negeri 1 PSEKSU Kab. Lahat? And what are the supporting and inhibiting factors of school principals in empowering administrative staff in SMA Negeri 1 PSEKSU Kab. Lahat ?. The purpose of this study was to determine the efforts of school principals in empowering administrative staff in SMA Negeri 1 PSEKSU in Lahat Regency and to know the supporting and inhibiting factors of school principals in empowering civil servants in the SMAN region. There is a type of data in research is a qualitative data that includes information about things that are related to the head of the school in empowerment of employees or businesses in SM Anegeri 1 PSEKSU Kab. Lahat. Sources of data in this study consisted of primary data and secondary data, primary data consisted of school principals, administrative staff and teachers, while secondary data were a number of supporting data in the form of documentation, archives and literature-literature that were subject to the research discussed. For data collection, researchers used observation techniques, interviews and documentation.
\end{abstract}

Then it was concluded that the efforts of the headmaster in empowering the administrative staff obtained in this study were, first, the principal had empowered quite well and was connected with the vision of the school. Second, the principal conducts empowerment directed towards using examples, third, establishes good communication with administrative staff, fourth, the principal reviews the school's organizational structure so that staff can find out their positions and tasks, fifth, the principal strengthen team / group keraja by means of communicating well, holding joint meetings, involving administrative staff to attend training, sixth, the principal encourages personal development of administrative staff with, seventh, the principal makes the service a focus so that it can attract interest community to register their children and can increase the number of students in high schools 1 Pseksu Kab. Lahat, and finally the principal conducts an evaluation. The supporting factors in empowering administrative staff are: First, there is trust between superiors and subordinates Second, mutual respect and mutual understanding of the opinions expressed Third, believe that empowerment will bring benefits to the school being led. While the inhibiting factors in the empowerment are: the number of administrative staff still little, the education level of administrative staff is still low, and the lack of funding to implement empowerment.

Keywords: Principal, Empowerment, Administration. 


\section{Pendahuluan}

Sekolah merupakan salah satu lembaga pendidikan yang dipercaya masyarakat dan negara untuk menyediakan sumber daya manusia yang dibutuhkan untuk perkembangan suatu bangsa. Untuk itu dibutuhkan seorang pemimpin yang didasarkan pada jati diri bangsa yang hakiki, bersumber nilai-nilai budaya dan agama serta mampu mengantisipasi perubahan yang terjadi di dunia pendidikan. ${ }^{44}$

Adapun pemimpin dalam suatu lembaga pendidikan adalah kepala sekolah, suatu lembaga pendidikan akan berhasil atau bahkan gagal sebagian besar ditentukan oleh kepemimpinan. ${ }^{45}$ Kepala sekolah adalah pemimpin pendidikan yang sangat penting, dikatakan sangat penting karena lebih dekat dan langsung berhubungan dengan pelaksanaan program pendidikan di sekolah. Dapat dilaksanakan atau tidaknya suatu program pendidikan dan tercapai atau tidaknya tujuan pendidikan itu, sangat bergantung pada kecakapan dan kebijaksanaan kepala sekolah sebagai pemimpin pendidikan.

Oleh karena itu seorang kepala sekolah harus mengetahui tugastugas yang harus dilakukannya agar dapat mencapai tujuan pendidikan yang sudah ditetapkan. Adapun tugas pokok kepala sekolah mencakup empat pola, yaitu:

1. Pemimpin, sebagai pemimpin kepala sekolah berfungsi menggerakkan semua potensi sekolah dalam pencapaian tujuan sekolah.

2. Pengelola Administrasi, seorang kepala sekolah bertugas menyelenggarakan administrasi sekolahnya.

3. Pembaharu, seorang kepala sekolah bertugas memperbaharui keadaan sekolahnya.

4. Pendorong, seorang kepala sekolah bertugas sebagai pendorong, pemberi motivasi terhadap semua komponen sekolahnya. ${ }^{46}$

Salah satu tugas pokok kepala sekolah adalah sebagai pengelola administrasi sekolah. Untuk meyelesaikan semua tugas khususnya dibidang administrasi sekolah, kepala sekolah mempunyai wewenang mendelegasikan tugasnya tersebut kepada staf yang ada di lingkungan sekolah. Adapun yang membantu kepala sekolah dalam menyelesaikan

44 Aan Komari \& Cepi Triatna, Visionary Leadership Menuju Sekolah Efektif (Jakarta: PT Bumi Aksara, 2006), hlm. 80.

${ }^{45}$ Miftah Thoha, Kepemimpinan dalam Manajemen, (Jakarta: PT Raja Grafindo Persada, 1998), hlm.1

$46 \mathrm{http} / /$ / website=smp3-bonang-.siles.wordpress.com Diakses pada tanggal 23 hari Rabu 2016

ÁL-FÂHIM | Vol I No. 2, September 2019 
tugas administrasi sekolah adalah pegawai tata usaha. Pegawai tata usaha bertugas melayani, menyimpan, mencatat serta menyediakan berbagai keterangan yang diperlukan oleh sekolah.

Secara operasional tata usaha sekolah berfungsi membantu kepala sekolah dalam kegiatan-kegiatan sebagai berikut:

1. Mengelola surat menyurat sekolah yang berkaitan dengan pembelajaran.

2. Mengelola keuangan sekolah.

3. Mengelola perlengkapan/sarana prasarana sekolah.

4. Pelaksana urusan kepegawaian, baik pendidik maupun tenaga kependidikan yang bertugas di sekolah.

5. Pelaksana kesiswaan seperti, pengaturan dan penyelenggaraan penerimaan siswa baru, pencatatan siwa baru dan siswa lama.

6. Mengantarkan surat keluar.

7. Memelihara dan memperbaiki fasilitas sekolah berupa bangunan dan peralatan praktik. ${ }^{47}$

Demikianlah kegiatan-kegiatan yang dilakukan oleh pegawai tata usaha dalam rangka membantu kepala sekolah terkait dengan urusan administrasi sekolah.

Keberadaan pegawai tata usaha juga sangat penting dalam mencapai tujuan pendidikan, sebagaimana telah ditetapkan Peraturan Menteri Pendidikan Nasional Republik Indonesia Nomor 24 Tahun 2008 Tanggal 11 Juni 2008 tentang "Standar Staf Administrasi Sekolah". Penentuan Standar ini wajib dipenuhi oleh pegawai tata usaha agar dapat melaksanakan pekerjaannya dengan baik. Akan tetapi fenomena yang sering terjadi di lapangan kadang-kadang kepala sekolah masih kurang menyadari akan pentingnya pegawai tata usaha bahkan tingkat pendidikan pegawai tata usaha di sekolah pada umumnya masih relatif rendah di antaranya ada yang berpendidikan SMA, SMP, bahkan ada yang tamatan SD. ${ }^{48}$

Oleh karena itu pegawai tata usaha sangat membutuhkan pemberdayaan dan motivasi kepala sekolah agar tugas dan pekerjaannya dapat terlaksana dengan baik. Pemberdayaan merupakan suatu kegiatan

47 Sudarwan Danim \& H. Khairil, Profesi Kependidikan, (Bandung: Alfabeta, 2012), hlm. 208

48 Afriyenti, Jurusan/Program Studi Administrasi Pendidikan FIP UNP, Jurnal Administrasi Pendidikan, Vol.1 No.1 Oktober 2013, http://download.Portalgaruda. Org/article. php?article=101314\&val=1537. Di aksespadahari Kamis tanggal 24 November 2016, hlm. 9 
untuk mengelola SDM lebih baik lagi. Kegiatan pemberdayaan dapat dilaksanakan dengan pengembangan kompetensi, pemberian wewenang dan tanggung jawab dalam rangka pelaksanaan kegiatan-kegiatan dapat meningkatkan kinerja pegawai sebagaimana yang diharapkan. ${ }^{49}$ Pemberdayaan dapat diawali dengan hanya sekedar memberikan dorongan kepada orang agar memainkan peran lebih aktif dalam pekerjaannya, sampai melibatkan mereka dalam mengambil tanggung jawab untuk menyelesaikan pekerjaan tersebut. ${ }^{50}$ Akhlak sangatlah penting bagi manusia. Akhlak ini tidak saja dirasakan oleh manusia dalam kehidupan perseorangan, tetapi juga dalam kehidupan berkeluarga dan bermasyarakat, bahkan juga dirasakan dalam kehidupan berbangsa dan bernegara. Akhlak sebagai mustika hidup yang membedakan manusia dari hewan. Manusia tanpa akhlak adalah manusia yang telah "membinatang", sangat berbahaya. Ia akan lebih jahat dan lebih buas dari binatang buas itu sendiri. ${ }^{51}$

Dengan demikian, pemberdayaan pegawai tata usaha yaitu mendorong mereka menjadi lebih giat dalam melaksanakan tugasnya sehingga dapat meningkatkan kemampuannya serta menumbuhkan rasa tanggung jawab terhadap tugas yang telah diberikan kepadanya.

Berdasarkan hasil observasi awal yang dilakukan peneliti, SMA Negeri 1 PSEKSU Kabupaten Lahat merupakan salah satu sekolah yang baru berdiri, sehingga dalam bidang administrasi/tata usaha, sekolah tersebut belum bisa dikatakan maksimal karena mengalami beberapa masalah. Adapun masalah-masalah tersebut yaitu: ${ }^{52}$

1. Kurangnya motivasi dan pemberdayaan kepala sekolah terhadap pegawai tata usaha sehingga dalam melaksanakan tugasnya pegawai tata usaha belum bisa memiliki rasa tanggung jawab sepenuhnya.

2. Jumlah pegawai tata usaha yang masih sedikit dan pegawai tata usaha tersebut bukan berasal dari tenaga kependidikan, sehingga dalam melaksanakan tugasnya seperti mengolah rancangan surat, mengurus penyimpanan surat, mengurus pengadaan formulir baik itu untuk siswa, guru dan lain sebagainya agak sedikit terhambat

\footnotetext{
49 Suwanto dan Donni Juni Priansa, Manajemen SDM dalam Organisasi Publik dan Bisnis, (Bandung: Alfabeta, 2013), hlm. 189

50 Wibowo, Manajemen Kinerja, (Jakarta: PT RajaGrafindo Persada, 2016), hlm. 351

51 Ahmad Wahyu Hidayat, Abdullah Idi, Nyayu Soraya, Hubungan Akhlak Mahmudah Terhadap Prestasi Belajar Siswa Kelas VII 1 SMP Muammadiyah 6 Palembang, Jurnal PAI Raden Fatah Vol. 1 No. 1 Januari 2019, hlm. 68-81.

52 Observasi awal pada tanggal 3 November 2016, Di SMA Negeri 1 PSEKSU Kabupaten Lahat.
}

ÁL-FÂHIM | Vol I No. 2, September 2019 
dikarenakan jumlah pegawai yang sedikit dan pegawai tersebut bukan dari tenaga kependidikan.

3. Kurangnya komunikasi antara kepala sekolah dan pegawai tata usaha sehingga tidak terjalin kerjasama yang baik, antara atasan dan bawahan. Oleh karena itu, berdasarkan latar belakang masalah tersebut maka peneliti tertarik untuk meneliti lebih lanjut tentang "Upaya Kepala Sekolah Dalam Pemberdayaan Pegawai Tata Usaha Di SMA Negeri 1 PSEKSU Kabupaten Lahat".

Berdasarkan permasalahan yang diuraikan pada latar belakang di atas maka rumusan masalah dalam penelitian ini yaitu: bagaimana upaya kepala sekolah dalam pemberdayaan pegawai tata usaha di SMA Negeri 1 PSEKSU Kabupaten Lahat?, Apa saja yang menjadi faktor pendukung dan penghambat kepala sekolah dalam pemberdayaan pegawai tata usaha di SMA Negeri 1 PSEKSU Kabupatesn Lahat?

\section{Metodologi Penelitian}

Penelitian ini menggunakan lapangan (field research) yaitu dengan mengadakan penelitian terhadap objek yang dituju untuk memperoleh data yang benar dan terpercaya tentang aktivitas guru Pendidikan Agama Islam dalam menanamkan sikap sosial kepada siswa. Penelitian yang dilaksanakan di lapangan adalah meneliti masalah yang sifatnya kualitatif, yakni prosedur data penelitian yang menghasilkan data deskriptif berupa kata-kata tertulis atau lisan dari para guru dan siswa.

Metode yang digunakan dalam penelitian ini adalah metode kualitatif atau disebut juga penelitian kualitatif. Penelitian kualitatif' adalah penelitian tentang riset yang bersifat deskriptif dan cenderung menggunakan analisis. Proses dan makna (perspektif subyek) lebih ditonjolkan dalam penelitian kualitatif. Landasan teori dimanfaatkan sebagai pemandu agar fokus penelitian sesuai dengan fakta di lapangan. Selain itu landasan teori juga bermanfaat untuk memberikan gambaran umum tentang latar penelitian dan sebagai bahan pembahasan hasil penelitian.

Sumber data dalam penelitian ini adalah Guru PAI SMA Nurul Iman, siswa Kelas X SMA Nurul Iman Palembang serta dokumen-dokumen yang berkaitan dengan permasalahan penelitian ini. Metode pengumpulan data dengan menggunakan observasi, wawancara, dan dokumentasi. Sedangkan analisis data dengan menggunakan Data Reduction (Reduksi data), Display (penyajian data), dan Verifikasi (menarik kesimpulan). 


\section{Kerangka Teori}

Dalam sebuah penelitian sangat dibutuhkan berbagai teori, karena teori itu sendiri sangat menentukan berhasil atau tidaknya hasil penelitian. Maka untuk membantu memecahkan masalah penelitian kali ini, diperlukan teori yang relevan dengan tujuan penelitian.

1. Kepala Sekolah

a. Pengertian Kepala Sekolah

Kepala sekolah adalah tenaga fungsional guru yang diberi tugas untuk memimpin suatu sekolah. ${ }^{53}$ Menurut (Surat Keputusan Menteri Penertiban Aparatur Negara No. 0296) kepala sekolah adalah guru yang mendapatkan tugas tambahan. ${ }^{54}$ Menurut Mondy, Noe dan Premaux kepala sekolah adalah individu yang biasanya menduduki jabatan yang memainkan peran sebagai adviser (staff khusus) tatkala bekerja dengan manajer lain terkait dengan urusan SDM. ${ }^{55}$

Jadi, kepala sekolah adalah seorang pimpinan pada suatu lembaga pendidikan yang diberi tugas untuk mengelola sumber daya yang ada supaya dapat mencapai tujuan pendidikan yang sudah ditetapkan.

b. Syarat-Syarat Kepala Sekolah

Berdasarkan surat keputusan Menteri Pendidikan Nasional nomor 13 tahun 2007 syarat-syarat untuk menjadi kepala sekolah diatur sebagai berikut: ${ }^{56}$

1) Kualifikasi Umum Kepala Sekolah/Madrasah adalah sebagai berikut:

a) Memiliki kualifikasi akademik sarjana (S1) atau diploma empat (D/IV) kependidikan atau non kependidikan pada perguruan tinggi yang terakreditasi.

b) Pada waktu diangkat sebagai kepala sekolah berusia setinggi-tingginya 56 tahun.

c) Memiliki pengalaman mengajar sekurang-kurangnya 5 tahun menurut jenjang sekolah masing-masing, kecuali di Taman Kanak-kanak/Raudhatul Athfal (TK/RA) memiliki pengalaman mengajar sekurang-kurangnya 3

53 Wahjosumidjo, Kepemimpinan kepala sekolah Tinjauan Teoretik dan permasalahan nya, (Jakarta: PT RajaGrafindo Persada, 2011), hlm.13

54 Supardi, Sekolah Efektif Konsep Dasar dan Praktiknya, (Jakarta: Rajawali Pers, 2013), hlm. 39

55 Syaiful Sagala, Manajemen Startegik dalam Peningkatan Mutu Pendidikan, (Bandung: Alfabeta, 2011), hlm. 88

56 Ibid., hlm. 28-31

ÁL-FÂHIM | Vol I No. 2, September 2019 
tahun di TK/RA.

d) Memiliki pangkat serendah-rendahnya III/c bagi pegawai negeri sipil (PNS) dan bagi non-PNS disetarakan dengan kepangkatan yang dikeluarkan oleh yayasan atau lembaga yang berwenang.

2) Kualifikasi Khusus Kepala Sekolah/Madrasah meliputi:

Kepala Sekolah Menengah Atas/Madrasah aliyah (SMA/MA) adalah sebagai beriku:

a) Berstatus sebagai guruSMA/MA

b) Memiliki sertifikat pendidik sebagai guru SMA/MA

c) Memiliki sertifikat kepala SMA/MA yang diterbitkan oleh lembaga yang ditetapkan pemerintah.

Syarat-syarat di atas pada lembaga pendidikan tertentu kriterianya dapat ditambahkan dan disesuaikan dengan kebutuhan lembaga sekolah masing-masing. Karena syarat di atas pada dasarnya merupakan syarat minimum yang harus dipenuhi oleh seorang kepala sekolah.

3) Kompetensi Kepala Sekolah

Di samping persyaratan di atas, terdapat sederetan persyaratan kemampuan yang harus dimiliki pula oleh seorang kepala sekolah sebagai kompetensinya yaitu: ${ }^{57}$

a) Kemampuan menganalisis persoalan (problemanalysis).

b) Kemampuan memberikan pertimbangan, pendapat, dan keputusan.

c) Kemampuan mengatur sumber daya dan berbagai macam kegiatan.

d) Kemampuan mengambil keputusan.

e) Kemampuan memimpin.

f) Bersifat lapang dada dan sabar (stresstolerance).

g) Kemampuan berkomunikasi secara lisan.

h) Kemampuan berkomunikasi secara tertulis.

i) Aktif berpartisipasi dan mendiskusikan berbagai macam persoalan yang berhubungan dengan sekolah.

j) Memiliki motivasi pribadi yangtinggi.

Demikianlah kompetensi/kemampuan yang harus dipenuhi oleh seorang kepala sekolah dalam memimpin suatu lembaga pendidikan supaya tujuan pendidikan dapat dicapai dengan baik.

57 Wahjosumidjo, Kepemimpinan kepala sekolah..., hlm. 394 
4) Tugas Kepala Sekolah

Sebagai seorang tokoh pimpinan yang menentukan suatu organisasi, kepala sekolah diberi tugas dan tanggung jawab untuk memimpin dan menggerakkan seluruh sumber daya yang ada agar dapat mencapai hasil sesuai dengan tujuan yang sudah ditetapkan. Menurut Terry (1993) adapun tugas kepemimpinan yaitu: 1) menetapkan visi dan misi, 2) menetapkan nilai, 3) menumbuhkan nilai, 4) memotivasi, 5) mengelola, 6) mencapai kesatuan kerja, 7) memberi penjelasan, 8) perwakilan kelompok, 9) pembaharu. ${ }^{58}$

Tugas kepemimpinan kepala sekolah tersebut akan berhasil dengan baik apabila seorang kepala sekolah memahami akan tugas yang harus dilaksanakannya. Oleh sebab itu kepala sekolah akan tampak dalam proses di mana dia mampu mengarahkan, membimbing serta mempengaruhi orang lain untuk mencapai tujuan bersama yang sudah ditetapkan.

2. Tata usaha

a. Pengertian Tata Usaha

Administrasi dalam arti sempit yaitu pengertian yang ditarik dari bahasa Belanda administratie yang sangat terbatas, hanya menyangkut sebagian kecil dari pengertian administrasi yang sesungguhnya terutama dimaksudkan dengan Tata Usaha yang diartikan sebagai kegiatan menyusun keteranganketerangan secara sistematis dan pencatatan-pencatatan semua keterangan yang diperlukan untuk meperoleh suatu ikhtisar/ringkasan mengenai keterangan dalam keseluruhanya, untuk bahan pertimbangan bagi pimpinan dalam mengambil atau menentukan langkah-langkah yang akan datang. ${ }^{59}$

Sedangkan pengertian tata usaha menurut Pedoman Pelayanan Tata usaha ialah segenap kegiatan pengelolaan surat-menyurat yang dimulai dari menghimpun (menerima), mencatat, mengolah, menggandakan, mengirim, dan menyimpan semua bahan yang diperlukan oleh organisasi. ${ }^{60}$

58 Supardi, Sekolah Efektif Konsep Dasar..., Op. Cit., hlm. 39-40

${ }_{59}$ Mufti Ahmad, Administrasi dan Supervisi Pendidikan, (Palembang: IAIN Raden Fatah Press, 2005), hlm. 4

60 Daryanto, Administrasi Pendidikan, (Jakarta: Rineka Cipta, 2013), hlm. 94

ÁL-FÂHIM | Vol I No. 2, September 2019 
Dari pengertian di atas dapat disimpulkan bahwa tata usaha yaitu suatu kegiatan melayani, mengolah, mengirim, serta mencatat keterangan-keterangan secara sistematis yang diperlukan oleh organisasi atau lembaga pendidikan agar dapat dijadikan bahan pertimbangan bagi pimpinan untuk menentukan langkah-langkah yang akan datang.

b. Ruang Lingkup TataUsaha

Adapun ruang lingkup tata usaha pada suatu lembaga pendidikan/sekolah yaitu: adanya organisasi dan struktur pegawai tata usaha, mencatat anggaran belanja sekolah, masalah kepegawaian, masalah keuangan dan pembukuanya, surat-menyurat, pengangkatan, pemindahan, penempatan dan pemberhentian pegawai dan pengisian buku induk serta raport para siswa. ${ }^{61}$

c. Kegiatan Tata Usaha pada Suatu lembaga/Sekolah

Di lembaga-lembaga pendidikan sejak dari tingkat terendah sampai pada tingkat tertinggi kegiatan administrasi tata usaha mencakup: ${ }^{62}$

1) Penerimaan Siswa/Mahasiswa Baru

a) Pengaturan dan penyelenggaraan teknis penerimaan siswa/ mahasiswa baru

b) Pencatatan siswa baru dan siswa lama

c) Pengaturan dan pencatatan siswa/mahasiswa yang lulus dan tidak lulus

d) Pengaturan dan pencatatan siswa yang tidak lulus yang berkeinginan untuk mengulang kembali

e) Mengadakan pencatatan siswa/mahasiswa yang drop out (keluar).

2) Mengatur daftar hadir/absensi

a) Absen guru

b) Absen murid

3) Mengatur dokumentasi kelas

4) Pengaturan/penjadwalan proses belajarmengajar

5) Mengatur dan menata buku administrasi tata usaha

a) Buku agenda surat masuk dan suratkeluar.

b) Buku daftar nominatif murid (buku induk siswa).

c) Buku daftar murid peringkat dan perkelas.

61 Syaiful Sagala, Manajemen Strategik dalam..., Op. Cit., hlm. 48

${ }_{62}$ Mufti Ahmad, Administrasi dan Supervisi..., Op. Cit., hlm. 58-59 


\section{d. Fungsi TataUsaha}

Adapun fungsi dari kegiatan-kegiatan tata usaha yaitu: 63

1) Menghimpun yaitu: kegiatan-kegiatan mencari data, mengusahakan tersedianya segala keterangan yang tadinya belum ada, sehingga siap untuk digunakan bilamana diperlukan.

2) Mencatat yaitu: kegiatan membubuhkan dengan berbagai peralatan tulis keterangan yang diperlukan sehingga terwujud tulisan yang dapat dibaca, dikirim dan disimpan.

3) Mengolah yaitu: bermacam kegiatan mengerjakan keterangan-keterangan dengan maksud menyajikan dalam bentuk yang lebih berguna.

4) Menggandakan yaitu: kegiatan memperbanyak dengan berbagai cara dan alat.

5) Mengirim yaitu: kegiatan menyampaikan dengan berbagai cara dan alat dari satu pihak kepihak yang lain.

6) Menyimpan yaitu: kegiatan menaruh dengan berbagai cara dan alat ditempat yang tertentu dan aman.

Dengan adanya tata usaha maka sangat membantu pihak pimpinan pada suatu organisasi/sekolah dalam membuat keputusan dan melakukan tindakan yang tepat. Dan tata usaha juga mempunyai peranan melancarkan kehidupan dan perkembangan suatu organisasi karena fungsinya sebagai pusat ingatan dan sumber dokumen. Pencatatan keterangan-keterangan itu selain untuk keperluan informasi juga bertalian dengan pertanggung jawaban dan fungsi kontrol pada suatu lembaga pendidikan, oleh karena itu pegawai tata usaha sangat dibutuhkan pada suatu lembaga pendidikan.

3. Pemberdayaan

a. Pengertian Pemberdayaan

Menurut Stewart secara etimologis pemberdayaan berasal dari kata power berarti kekuasaan, yaitu kemampuan untuk mengusahakan agar sesuatu itu terjadi ataupun tidak sama sekali. Sedangkan menurut Noe et. al pemberdayaan

63 Daryanto, Administrasi Pendidikan..., Op. Cit., hlm. 93-94

ÁL-FÂHIM | Vol I No. 2, September 2019 
merupakan pemberian tanggung jawab dan wewenang terhadap pekerjaan untuk mengambil keputusan. ${ }^{64}$ Sementara itu Robbins memberikan pengertian bahwa pemberdayaan sebagai menempatkan pekerja agar bertanggung jawab atas apa yang mereka kerjakan. ${ }^{65}$

Dengan demikian, pemberdayaaan merupakan suatu proses untuk menjadikan orang menjadi lebih berdaya atau lebih berkemampuan untuk menyelesaikan pekerjaannya sendiri, dengan cara memberikan kepercayaan dan wewenang sehingga menumbuhkan rasa tanggung jawabnya.

b. Strategi Pemberdayaan

Menurut Cook dan Macualy, strategi pemberdayaan SDM didasarkan atas delapan buah langkah menuju keberhasilan, yaitu:

1) Hubungan dengan visi

2) Diarahkan dengan menggunakan contoh-contoh

3) Berkomunikasi secara aktif

4) Meninjau struktur organisasi

5) Menguatkan kerja tim

6) Mendorong pengembangan pribadi

7) Menjadikan jasa layanan kepada pelanggan sebagai fokus

8) Ukur perkembangan yang terjadi dan kenali serta hargai keberhasilan. ${ }^{66}$

Pemberdayaan merupakan suatu kegiatan untuk mengelola SDM lebih baik lagi. Untuk itu seorang pemimpin perlu melakukan strategi pemberdayaan sehingga para bawahanya dapat melakukan pekerjaannya sesuai dengan bidangnya.

c. Tujuan Pemberdayaan

Adapun tujuan dari pemberdayaan SDM, yaitu terwujudnya SDM yang:

1) Mempunyai/memiliki kemampuan (competency)

2) Mempunyai wewenang yang jelas

3) Mempunyai tanggung jawab (responsibility) yang

64 Suwatno dkk, Manajemen SDM dalam Organisasi Publik dan Bisnis, (Bandung: Alfabeta, 2013), hlm. 182

65 Wibowo, Manajemen Kinerja, (Jakarta: PT RajaGrafindo Persada, 2016), hlm. 350

66 Ibid., hlm. 187-188 
akuntabel. ${ }^{67}$

Dengan demikian, pemberdayaan dapat meningkatkan kemampuan dan rasa memiliki, serta meningkatkan rasa tanggung jawab para pegawai atau karyawan pada suatu organisasi atau lembaga pendidikan.

d. Indikator Pemberdayaan

Penilaian haruslah dilakukan untuk mengukur sejauh mana pemimpin suatu organisasi atau lembaga pendidikan melakukan pemberdayaan terhadap pegawai atau karyawannya.

Menurut Cook dan Macaulay, strategi ataupun cara dalam pemberdayaan SDM didasarkan atas delapan buah langkah menuju keberhasilan yaitu: 1) hubungan dengan visi, 2) diarahkan dengan menggunakan contoh-contoh, 3) berkomunikasi secara aktif, 4) meninjau struktur organisasi, 5) menguatkan kerja tim, 6) mendorong pengembangan pribadi, 7) menjadikan jasa layanan kepada pelanggan sebagai fokus, 8) evaluasi. ${ }^{68}$

Dengan berlandaskan teori di atas maka peneliti dapat menjadikan penilaian ataupun indikator yang harus dilakukan oleh seorang kepala sekolah dalam pemberdayaan pegawai tata usaha di lembaga pendidikan ataupun sekolah yang dipimpinnya. Adapun indikatorindikator tersebut yaitu:

1) Kepala sekolah memberikan tugas atau pekerjaan kepada pegawai tata usaha berdasarkan visi yang sudah dibuat bersama.

2) Kepala sekolah memberikan tugas serta pekerjaan kepada pegawai tata usaha dengan diarahkan menggunakan contoh-contoh.

3) Kepala sekolah menjalin komunikasi yang aktif terhadap pegawai tata usaha sehingga terciptanya hubungan kerja yang baik.

4) Kepala sekolah harus membuat serta meninjau struktur organisasi sehingga pegawai tata usaha mengetahui tugas dan tanggung jawabnya.

67Ibid., hlm. 190

68 Suwatno dkk, Manajemen SDM dalam Organisasi Publik dan Bisnis, (Bandung: Alfabeta, 2013), hlm. 187-188

ÁL-FÂHIM | Vol I No. 2, September 2019 
5) Kepala sekolah haruslah menguatkan kerja tim kepada para pegawai tata usaha baik itu dengan cara mengadakan diskusi-diskusi ilmiah terkait dengan masalah administrasi sekolah ataupun dengan cara menjalin komunikasi yang baik.

6) Kepala sekolah memberikan motivasi kepada pegawai tata usaha sehingga dapat mendorong pengembangan pribadi mereka dan dapat meningkatkan kinerjanya terhadap tugas dan pekerjaannya.

7) Kepala sekolah harus menjadikan jasa layanan sebagai fokus utama kepada pegawai tata usaha, sehingga dengan adanya pelayanan yang baik maka dapat mendorong para masyarakat untuk memasukkan anak-anak mereka ke sekolah tersebut sehingga dapat meningkatkan jumlah peserta didiknya.

8) Kepala sekolah mengadakan evaluasi terhadap tugastugas pegawai tata usaha yang sudah dilakukannya dan memberikan reward kepada pegawai tata usaha yang berprestasi dan disiplin terhadap tugas dan pekerjaanya.

\section{B. Tinjauan Pustaka}

Tinjauan Pustaka adalah uraian tentang hasil penelitian terdahulu yang relevan dengan penelitian yang sedang di rencanakan guna mengetahui persamaan dan perbedaan skripsi yang akan dilakukan oleh peneliti. Adapun penelitian-penelitian tersebut antara lain:

Pertama, Skripsi yang ditulis oleh saudara Sumbandri Mahasiswa Fakultas Tarbiyah dan Keguruan Institut Agama Islam Negeri Raden Fatah Palembang pada tahun 2012, dengan judul "Upaya Kepala Madrasah Dalam Meningkatkan Kinerja Guru Di MTS Babul Falah Desa Tanjung Bunut Kecamatan Lembak Kab. Muara Enim". Dalam penelitiannya menyatakan bahwa kepala madrasah telah melaksanakan uapayanya untuk meningkatkan kinerja guru dengan mengadakan observasi kelas dan meneliti suasana kelas selama pelajaran berlangsung, mengadakan dialog dengan guru dalam memecahkan masalah-masalah pribadi yang ada hubunganya dengan 
proses pembelajaran, memberikan penghargaan kepada guru yang berprestasi dan memberikan sanksi kepada guru yang kurang disiplin. ${ }^{69}$

Berbeda dengan penelitian yang akan diteliti peneliti, peneliti lebih mengarah pada peningkatan kerja pegawai tata usaha di sekolah seperti pengambilan keputusan dalam menyelesaikan pekerjaannya. Adapun persamaan skripsi tersebut dengan skripsi peneliti yaitu sama-sama menjelaskan bahwa, untuk meningkatan kinerja pegawai baik itu guru, tata usaha dan pegawai lainya kepala sekolah hendaklah memberikan suatu penghargaan kepada pegawai yang bekerja dengan baik dan disiplin, sehingga dengan adanya penghargaan tersebut maka akan meningkatkan semangat pegawai untuk melakukan pekerjaannya agar menjadi lebih baik lagi.

Kedua, Skripsi yang ditulis oleh saudari Sulastri Mahasiswa Fakultas Ilmu Pendidikan Universitas Negeri Padang pada tahun 2013, dengan judul "Upaya Kepala Sekolah Dalam Menciptakan Iklim Komunikasi Yang Kondusif Di SMP N 1 Padang". Pada skripsi ini menjelaskan tentang bagaimana kepala sekolah menciptakan komunikasi yang baik di dalam sekolah baik sesama rekan maupun kepada pegawai lainnya, sehingga terjalin kerjasama yang baik antara atasan dan bawahan dan dapat mencapai tujuan sekolah yang sudah ditetapkan sebelumnya. ${ }^{70}$

Berbeda dengan penelitian yang akan dilakukan peneliti yaitu upaya kepala sekolah dalam pemberdayaan pegawai tata usaha, sehingga kepala Institut Agama Islam Negeri Raden Fatah, 2012). sekolah mempunyai peranan yang sangat penting untuk memberikan dorongan/motivasi kepada pegawai tata usaha agar melaksanakan tugasnya dengan baik dan lebih bertanggung jawab lagi. Adapun persamaan skripsi tersebut dengan peneliti adalah sama-sama menjelaskan bahwa kepala sekolah sangat penting untuk menjalin komunikasi yang baik di sekolah, dengan adanya komunikasi yang baik antara atasan dan bawahan maka akan terjadi kerjasama yang baik pula, sehingga dapat mencapai tujuan bersama yang sudah ditetapkan.

Ketiga, Skripsi yang ditulis oleh saudari Melisa Mayang Sari Mahasiswa Fakultas Tarbiyah Dan Keguruan Institut Agama Islam Negeri Raden Fatah Palembang pada tahun 2014, dengan judul “Upaya Kepala

69Sumbandri,Skripsi: “Upaya KepalaMadrasahDalam Meningkatkan KinerjaGuru Di MTS Babul Falah Desa Tanjung Bunut Kecamatan Lembak Kab. Muara Enim", (Palembang: Raden press, 2012), hlm. 78.

70Sulastri, Skrispsi: "Upaya Kepala Sekolah Dalam Menciptakan Iklim Komunikasi Yang Kondusif Di SMP N 1 Padang", (Padang: Universitas press, 2013). hlm. 32.

ÁL-FÂHIM | Vol I No. 2, September 2019 
Sekolah Dalam Meningkatkan Kinerja Tenaga Kependidikan Di SMA Muhammadiyah 2 Palembang". Adapun fokus utama penelitian ini adalah membahas tentang bagaimana upaya kepala sekolah dalam meningkatkan kinerja tenaga kependidikan yang sudah memiliki kemampuan, tetapi usaha untuk mengembangkan kemampuan tersebut harus ditingkatkan agar menjadi lebih baik lagi. ${ }^{71}$

Berbeda dengan penelitian yang akan diteliti peneliti, peneliti lebih membahas kepada upaya kepala sekolah dalam pemberdayaan pegawai tata usaha, dan apa saja yang akan dilakukan kepala sekolah dalam pemberdayaan pegawai tata usaha agar pegawai tata usaha tersebut lebih bertanggung jawab terhadap tugas yang diberikan kepadanya. Adapun persamaan skripsi tersebut dengan peneliti adalah sama-sama menjelaskan bagaimana upaya kepala sekolah dalam meningkatkan kinerja pegawai, tetapi usaha untuk mengembangkan kemampuan tersebut harus ditingkatkan agar menjadi lebih baik lagi, dengan demikian diperlukan pemberdayaan oleh kepala sekolah agar pegawai tata usaha dapat melaksanakan tugasnya dengan baik dan lebih bertanggung jawab lagi terhadap pekerjaannya. ${ }^{72}$

Dari ketiga penelitian diatas secara umum lebih membahas kepada peningkatan kinerja guru, peningkatan kinerja kependidikan dan upaya kepala sekolah menciptakan komunikasi yang baik, sedangkan peneliti disini lebih membahas kepada kinerja pegawai tata usaha. Danjika dicermati lebih jauh, penelitian yang telah disebutkan di atas belum ada yang membahas secara khusus tentang "Upaya Kepala Sekolah dalam pemberdayaan Pegawai Tata Usaha/Administrasi". Maka dari itu, penelitian diatas dapat dijadikan bahan pertimbangan untuk mengembangkan penelitian yang akan peneliti lakukan.

\section{Hasil Penelitian}

Upaya yang dilakukan kepala sekolah dalam pemberdayaan pegawai tata usaha di SMA Negeri 1 Pseksu Kab. Lahat yaitu: pertama kepala sekolah sudah melakukan pemberdayaan dengan cukup baik dan dihubungkan dengaan visi sekolahnya. Kedua, kepala sekolah melakukan pemberdayaan dengan diarahkan menggunakan contoh-contoh sehingga para pegawai lainnya dapat mencontoh apa yang telah dilakukan kepala sekolah, ketiga, menjalin komunikasi yang baik terhadap para pegawai tata

${ }^{71}$ Melisa Mayang Sari, Skripsi: “Upaya Kepala Sekolah Dalam Meningkatkan Kinerja Tenaga Kependidikan Di SMA Muhammadiyah 2 Palembangi", (Palembang: Universitas Negeri Islam Raden Fatah, 2014).

72 http://tata-usaha.blogspot.co.id/2010/06/pengertian-tata-usaha.html Diakses pada hari Minggu tanggal 20 November 2016 
usaha, keempat, kepala sekolah meninjau struktur organisasi sekolah tersebut agar para pegawainya dapat mengetahui posisi dan tugas-tugas mereka, kelima, kepala sekolah menguatkan keraja tim/kelompok dengan cara melakukan komunikasi dengan baik, mengadakan rapat bersama, mengikut sertakan pegawai tata usaha untuk mengikuti pelatihan agar dapat meningkatkan kemampuan mereka dalam melakukan tugasnya dan dapat menambah pengetahuan mereka, keenam, kepala sekolah mendorong pengembangan pribadi pegawai tata usaha dengan cara memberikan kepercayaan dan wewenang terhadap tugas yang mereka lakukan, ketujuh, kepala sekolah menjadikan jasa layanan sebagai fokus sehingga dapat menarik minat masyarakat untuk mendaftarkan anak-anak mereka dan dapat meningkatkan jumlah peserta didik di sekolah SMA Negeri 1 Pseksu Kab. Lahat, dan yang terakhir kepala sekolah melakukan evaluasi terhadap pekerjaan yang sudah di lakukan pegawai tata usaha.

Adapun kondisi pegawai tata usaha di SMA Negeri 1 Pseksu Kab. Lahat yaitu: jika dilihat dari tingkat pendidikan pegawai tata usaha sebagian mereka berpendidikan SMA dan sebagian sudah berpendidikan S1, akan tetapi kepala Tata usaha yang dipilih belum berdasarkan tingkat pendidikan mereka, namun jika dilihat dari tugas-tugas dan pelayanan yang sudah dilakukan oleh pegawai tata usaha sudah cukup baik, akan tetapi sebagian pegawai tata usaha ada yang jarang masuk ke sekolah sehingga kepala sekolah memberikan surat peringatan kepada pegawai tata usaha tersebut, dengan adanya surat peringatan tersebut maka pegawai tata usaha menyadari tugas dan tanggung jawab mereka sebagai pegawai tata usaha.

Adapun faktor pendukung dalam pemberdayaan pegawai tata usaha yaitu: Pertama, adanya kepercayaan antara atasan dan bawahan Kedua, saling menghargai dan saling pengertian terhadap pendapat yang disampaikan Ketiga, percaya bahwa pemberdayaan akan mendatangkan manfaat terhadap sekolah yang dipimpin khususnya dalam urusan administrasi sekolah. Sedaangkan faktor penghambat dalam pemberdayaan yaitu: jumlah pegawai tata usaha yang masih sedikit, tingkat pendidikan pegawai tata usaha yang masih rendah, serta kurangnya pembiayaan untuk melaksanakan pemberdayaan.

\section{Kesimpulan.}

Upaya kepala sekolah dalam pemberdayaan pegawai tata usaha yang diperoleh dalam penelitian ini yaitu Pertama, adanya kepercayaan antara atasan dan bawahan sehingga terlaksananya pekerjaan administrasi, dengan adanya saling mempercayai maka akan dapat membangun hubungan kerja yang baik antara kepala sekolah dan pegawai tata usaha sehingga dapat menghasilkan kinerja yang baik juga dan sesuai dengan apa

ÁL-FÂHIM | Vol I No. 2, September 2019 
yang direncanakan. Kedua, kepala sekolah menghargai dan memberikan pengertian terhadap pendapat yang disampaikan oleh pegawai tata usaha, dengan saling menghargai pendapat maka para pegawai tata usaha berani mengungkapkan pendapat mereka masingmasing dan dapat bekerjasama dengan baik terkait dengan urusan administrasi sekolah, dengan adanya kerjasama yang baik antara kepala sekolah dan pegawai tata usaha maka dapat mendukung kegiatan yang dilakukan oleh pegawai tata usaha, sehingga menimbulkan hasil yang memuaskan. Ketiga, sebagai kepala sekolah harus mempunyai rasa percaya diri bahwa pemberdayaan terhadap pegawai tata usaha akan mendatangkan manfaat terhadap sekolah yang dipimpin, khususnya dalam urusan administrasi sekolah sehingga pegawai tata usaha mampu menjadikan pelayanan yang lebih baik lagi dan tugas-tugas yang mereka lakukan sesuai dengan apa yang diperintahkan oleh kepala sekolah. Dengan adanya faktor pendukung tersebut maka pemberdayaan dapat dilakukan oleh kepala sekolah kepada pegawai tata usaha di SMA Negeri 1 Pseksu Kab. Lahat.

\section{Daftar Pustaka}

Aan Komari \& Cepi Triatna, Visionary Leadership Menuju Sekolah Efektif, Jakarta: PT Bumi Aksara, 2006.

Afriyenti, Jurusan/Program Studi Administrasi Pendidikan FIP UNP, Jurnal Administrasi Pendidikan, Vol.1 No.1 Oktober 2013, http://download.Portalgaruda.Org/ article. php?article $=101314 \& v a l=1537$. Di akses pada hari Kamis tanggal 24 November 2016, hlm. 9

Daryanto, Administrasi Pendidikan, Jakarta: Rineka Cipta, 2013.

http///website=smp3-bonang-.siles.wordpress.com Diakses pada tanggal 23 hari Rabu 2016

http:/ / tata-usaha.blogspot.co.id/2010/06/ pengertian-tata-usaha.html Diakses pada hari Minggu tanggal 20 November 2016

Hidayat, Ahmad Wahyu. Abdullah Idi, Nyayu Soraya, Hubungan Akhlak Mahmudah Terhadap Prestasi Belajar Siswa Kelas VII 1 SMP Muammadiyah 6 Palembang, Jurnal PAI Raden Fatah Vol. 1 No. 1 Januari 2019, hlm. 68-81.

Melisa Mayang Sari, Skripsi: “Upaya Kepala Sekolah Dalam Meningkatkan Kinerja Tenaga Kependidikan Di SMA Muhammadiyah 2 Palembangi", Palembang: Universitas Negeri Islam Raden Fatah, 2014.

Miftah Thoha, Kepemimpinan dalam Manajemen, Jakarta: PT Raja Grafindo Persada, 1998.

Mufti Ahmad, Administrasi dan Supervisi Pendidikan, Palembang: IAIN Raden Fatah Press, 2005. 
Sudarwan Danim \& H. Khairil, Profesi Kependidikan, Bandung: Alfabeta, 2012.

Sulastri, Skrispsi: “Upaya Kepala Sekolah Dalam Menciptakan Iklim Komunikasi Yang Kondusif Di SMP N 1 Padang", Padang: Universitas press, 2013.

Sumbandri, Skripsi: “Upaya Kepala Madrasah Dalam Meningkatkan Kinerja Guru Di MTS Babul Falah Desa Tanjung Bunut Kecamatan Lembak Kab. Muara Enim", Palembang: Raden press, 2012.

Supardi, Sekolah Efektif Konsep Dasar dan Praktiknya, Jakarta: Rajawali Pers, 2013.

Suwanto dan Donni Juni Priansa, Manajemen SDM dalam Organisasi Publik dan Bisnis, Bandung: Alfabeta, 2013.

Suwatno dkk, Manajemen SDM dalam Organisasi Publik dan Bisnis, Bandung: Alfabeta, 2013.

Syaiful Sagala, Manajemen Startegik dalam Peningkatan Mutu Pendidikan, (Bandung: Alfabeta, 2011

Wahjosumidjo, Kepemimpinan kepala sekolah Tinjauan Teoretik dan permasalahan nya, Jakarta: PT RajaGrafindo Persada, 2011.

Wibowo, Manajemen Kinerja, Jakarta: PT RajaGrafindo Persada, 2016. 